\title{
Diflubenzuron Effectiveness in Cattle Tick (Rhipicephalus Boophilus microplus) Control in Field Conditions
}

Renato Andreotti ${ }^{*}$, Marcos Valerio Garcia ${ }^{1}$, Jaqueline Matias ${ }^{2}$, Jacqueline Cavalcante Barros ${ }^{1}$, Georgia Mode Magalhaes ${ }^{4}$, Francisca de Assis Ardson $^{3}$ and Andre Rangel de Abreu Aguirre ${ }^{2}$

${ }^{1}$ Animal health, Embrapa Beef Cattle, Campo Grande-MS, Brazil

${ }^{2}$ Pos graduate program in infectious and parasitic diseases, Federal University of Mato Grosso do Sul, Campo Grande-MS, Brazil

${ }^{3}$ Unesp, Jaboticabal, São Paulo, Brazil

${ }^{4}$ Unifran, Franca, São Paulo, Brazil

\begin{abstract}
Considerable economic losses are currently caused by Rhipicephalus microplus, a cattle ectoparasite occurring in tropical and subtropical areas. Significant efforts to control this tick are made in most of the bovine producing countries, mainly with acaricides. Chemical control, albeit predominant, has been hampered by poor utilization of active principles, leading to development of resistance. This work has the objective of evaluating the diflubenzuron activity as a larvicide in cattle tick control in the field conditions. Thirty females of the $3 / 4$ Holstein $\times 1 / 4$ Zebu breed were used, half for each group during a year were, the control group and the group treated with diflubenzuron $3 \%$, which was provided with the salt in the trough, available to all animals throughout the day. The animals were managed every 14 days for tick count, weight verification and to observe their well-being. Animals having above 100 engorged ticks were treated by spraying (DDVP - Diclorvós, 60 grams, Clorpirifós, 20 grams, and solution, 20 grams). Based on tick biology and histology the Diflubenzuron $3 \%$ did not affect the development of ticks that survived the parasitic phase. The effect is in the tick larvae only and the efficacy is about $54,6 \%$ of protection using Diflubenzuron $3 \%$ in the salt. The use of acaricides when associated to diflubenzuron $3 \%$ reduce in $71 \%$ the use these acaricides and the cost of acaricide in aspersion represent when compared with diflubenzuron $3 \%$ only $7,9 \%$. The use of diflubenzuron $3 \%$ associated with chemical control is an effective proposal to cattle tick control with low contamination that should be thought by the production chain their cost/benefit taking into account the economic and environmental issues.
\end{abstract}

Keywords: Larvicide; Parasites; Bovines; Milk; Meat

\section{Introduction}

Parasites affect the well-being of bovines, and consequently herd productivity. Considerable economic losses are currently caused by Rhipicephalus microplus, a cattle ectoparasite occurring in tropical and subtropical areas [1]. The economic impact of the Rhipicephalus microplus cattle tick in Brazil is estimated to be around US\$ 3.24 billion every year [2].

Significant efforts to control this tick are made in most of the bovine producing countries, mainly with acaricides. However, $R$. microplus populations resistant to acaricides became a serious issue in most of these countries, therefore making the study of new strategies and the development of new technologies for tick control necessary to maintain the efficiency in bovine production [3-5].

It is widely known that the main form of control of this ectoparasite still is by the use of synthetic acaricides, what has been happening since the XIX century. According to Furlong et al. [6], the chemical compounds include the organophosphates, amidines, pyrethroids, phenylpyrazoles, cymiazole, naturalyte (contact acaricides), macrocyclic lactones, phenylpyrazoles (systemic), and more recently, the fluazuron.

Chemical control, albeit predominant, has been hampered by poor utilization of active principles, leading to development of resistance and requiring the use of increased concentrations of active compounds and more frequent application each year [7].

The excessive and incorrect use of adulticides employed to control other parasites, such as the Haematobia irritans fly [8-10], led to the exasperation of the resistance situation that can be found in the country, where it can be observed that the ticks developed resistance to practically all commercially available adulticides [3].

To mitigate the economic losses caused by ticks, new management strategies and technologies have been developed. Initially, the use of larvicides as food additives for parasite control became common [11].Then, the knowledge of the mechanisms involved in the insects molting process led to the development of insect growth inhibitors (IGRs), causing physiological and morphological modifications by the chitin synthesis inhibition during the insects' immature stage [12]

The most commonly used IGRs for pest control belong in the benzoyl-phenyl-urea group [13]. The Diflubenzuron, 1-(4-clorophenyl)-3- (2,6-difluorobenzoyl) urea, is one of the insect growth inhibitors that inhibits chitin synthesis, having ovicidal and larvicidal properties $[14,15]$, and it is effective only in stages where the cuticle deposition is needed for insect growth [16].

In addition to the larvicide property, the Diflubenzuron, as well as other derivatives of the benzoyl phenyl urea, are compounds that interrupt the reproductive process of insects and pests. The females

${ }^{*}$ Corresponding author: Renato Andreotti, Animal Health, Embrapa Beef Cattle. Av. Radio Maia $n^{\circ} 830$, Zona Rural, CEP 79106-550, Campo Grande, MS, Brazil, Tel: +55 (67) 3368-2173 ; E-mail: renato.andreotti@embrapa.br

Received March 30, 2015; Accepted May 28, 2015; Published June 04, 2015

Citation: Andreotti R, Garcia MV, Matias J, Barros JC, Magalhaes GM, et al. (2015) Diflubenzuron Effectiveness in Cattle Tick (Rhipicephalus Boophilus microplus) Control in Field Conditions. Pharm Anal Acta 6: 373. doi:10.4172/21532435.1000373

Copyright: @ 2015 Andreotti R, et al. This is an open-access article distributed under the terms of the Creative Commons Attribution License, which permits unrestricted use, distribution, and reproduction in any medium, provided the original author and source are credited. 
that ingest the compounds contaminate their own ovaries, and subsequently their eggs. Therefore, the embryos do not develop and the larvae do not hatch [16].

Considering the efficiency decrease of all adulticides products available on the market and the growing preoccupation with the residue accumulation in products of animal origin, this work has the objective of evaluating the diflubenzuron activity as a larvicide in cattle tick control in the field conditions.

\section{Material and Methods}

\section{Field assay}

The experiment was performed at Embrapa Beef Cattle (20'26'23.7'S $54^{\circ} 43^{\prime} 36.9^{\prime \prime} \mathrm{W}$ ), in the municipality of Campo Grande - MS - Brazil, in the period of January 2012 to April 2013. The pasture was composed of Brachiaria brizantha, with a stocking rate of 4 animals per hectare. The animal groups were separated by fences, and each group had separate access to water and food supply.

Thirty females of the $3 / 4$ Holstein $\times 1 / 4$ Zebu breed, with age above one year and a half and weight varying from 195 to $369 \mathrm{~kg}$ were used, half for each group. The animals beyond of pasture were supplemented daily with silage and concentrate (corn $18.5 \%$; soybean meal $73.1 \%$ ), in the proportion of $10 \mathrm{~kg} / 2 \mathrm{~kg}$, respectively, per animal per day. All cattle used in the experiment were raised on the research station and were exposed to low levels of cattle tick infestation during the previous year.

Before the beginning of the experiment the animals were identified, weighted and had their ticks controlled. The studied groups were: control group and the group treated with diflubenzuron 3\%, which was provided with the salt in the trough, available to all animals throughout the day. The tested product was mixed with mineral salt, in the proportion of $10 \mathrm{~g} / \mathrm{Kg}$. The average daily expected consumption was of $100 \mathrm{~g}$ of salt and $1 \mathrm{~g}$ of the product, being $30 \mathrm{mg}$ of diflubenzuron.

The animals were supplemented for three months with diflubenzuron $3 \%$, before tick infestation, which was done with 5,000 larvae for each animal to guarantee an uniform infestation. The animals were managed every 14 days for tick count, weight verification and to observe their well-being.

The ticks that cause economic harm in bovines in Brazil are only from the $R$. microplus species. All ticks $4.5 \pm 8.5 \mathrm{~mm}$ long on the whole of one side of each cow were counted, as ticks of this size have been shown to drop the following day [17].

Animals having above 100 engorged ticks were treated by spraying (each $100 \mathrm{ml}$ of the product contained: DDVP - Diclorvós, 60 grams, Clorpirifós, 20 grams, and solution, 20 grams. For each treated animal, $10 \mathrm{~mL}$ of the product was diluted in 4 liters of water).

The tick counts were conducted at seven up to 14 days intervals on the right side of each cow individually contained within squeeze chute; only female above $4.5 \mathrm{~mm}$ length were considered, as ticks of this size have been shown to drop the following day and, the final value was obtained by multiplying the observed value by two $[17,18]$.

\section{Economic evaluation}

The treatment costs were calculated using the diflubenzuron $3 \%$ market value of USD\$1.87, per animal per month and, the cost of the acaricide dose, with a market value of USD\$ 0.36 , including the number of doses used during the period of the experiment.

\section{Biology of ticks}

To observe the ticks' biological development in each group the following procedure was followed: engorged females were collected when the count was made and taken to the laboratory to be washed, dried, counted and weighted with an analytical scale, to be posteriorly incubated in an incubator with a $27+/-2^{\circ} \mathrm{C}$ temperature and $80 \%$ humidity [19]. Efficacy calculation was developed according Cunha et al. [17].

For the histological assays, to analyze the ticks' tissues, $R$. microplus from the same strain were used. Two treated bovines and two untreated bovines were used for tick development, and the ticks from each group were posteriorly compared [20].

The ticks were collected in the larvae, nymph and young adult stages (fourth, eight and thirteenth day after infestation, respectively). All the material for histopathological analysis was immersed in buffered formaldehyde for tissue fixation and sent to the laboratory, where they were submitted to a routine histological processing and embedded in paraffin. Posteriorly, the tissues were cut longitudinally and inked with Hematoxilin-Eosin and Giemsa, to be finally analyzed at Histopathology Laboratoty at Universidade Estadual de São Paulo (FCAV/Jaboticabal/SP/Brazil).

\section{Statistical analyze}

The data was analyzed using the BioEstat 5.0 program, using Mann-Whitney to compare averages of total detached engorged females for each group at the end of the trial, Wilcoxon to compare paired samples of biweekly average recovery rate of detached engorged females per animal from each group (Table 1) and compare average cattle weight before and after this trial, for the treated group (this group have presented different variances before and after the treatment) and paired sample $t$-Test to compare the same for the control group (equivalent variances). The Wilcoxon test was also used to compare the average cattle biweekly weight variation during the trial period of both groups by subtracting the average weight of each measurement by the last measurement until the end of the trial (Table 2). All tests were performed with a $5 \%$ significance.

\section{Results and discussion}

Field observations: The results showed that in the field infestation test, on 27 counts of engorged ticks evenly distributed over the period of one year, were observed the average per animal of 53.13 and 124.9 ticks to Diflubenzuron 3\% and control group, respectively (Figure 1). This represents a $57.6 \%$ tick reduction for the treated group.

The parasite phase begins with the infecting larva's arrival on the host, where it feeds itself with lymph and becomes a metalarva, which will suffer metamorphosis and become the nymph. The process repeats itself, generating a sexually defined individual. These adults, as semiengorged ticks, feed on blood, preparing to reproduce, and then the females evolve to engorged female ticks, the point in which they are ready to drop.

Each instar period may vary, depending on climatic conditions, such as temperature and humidity. In the period of the experiment from April 2012 to march 2013 the maximum temperature average was $32.7^{\circ} \mathrm{C}$ and the average minimum temperature was $14.3^{\circ} \mathrm{C}$, with rainfall of $1,794 \mathrm{~mm}$, while in the dry season from May of 2012 to October 2012 with rainfall of $540.7 \mathrm{~mm}$ that means $30.13 \%$ of annual rain.

The results showed that the average of the treated group was close 
Citation: Andreotti R, Garcia MV, Matias J, Barros JC, Magalhaes GM, et al. (2015) Diflubenzuron Effectiveness in Cattle Tick (Rhipicephalus Boophilus microplus) Control in Field Conditions. Pharm Anal Acta 6: 373. doi:10.4172/21532435.1000373

Page 3 of 7

to half of what we define as the limit for treatment with spraying of 100 ticks and, the average of the control group was above that.

In previous results shown by Oliveira et al. [21] the tick number for treated animals was on average only 5 individuals and the control obtained 56.7 ticks, meaning 10 times. In this case was conducted experiment with cross beef cattle Nellore $x$ Red Angus instead 3/4 Holstein $\mathrm{x} 1 / 4$ Zebu in this work and a maximum for treatment with acaricide was 80 ticks per host.

Histopathology and biology of tick: In the histopathological examination showed that ticks in the control group had a marked amount of erythrocytes and salivary glands well developed (Figure $2 \mathrm{~A}$ and $2 \mathrm{~B}$ ). The ticks of control group with 15 days (Figure $2 \mathrm{C}$ ) also showed marked amount of blood, but with hemosiderin diffusely distributed by tick.

With five days of treatment was remarkable to note the decrease of erythrocytes with hydropic degeneration of glandular epithelial cells (Figure 2D). The salivary glands were stunted in tick up to ten days of treatment, although there was karyolysis and vacuolated cytoplasm (Figure 2E). Erythrocytes at this stage were no longer observed. Ticks

\begin{tabular}{|c|c|c|}
\hline Group & Total detached engorged females/animal $^{\star}$ & Biweekly recovery rate of detached engorged females/animal $^{\star *}$ \\
\hline Diflubenzuron (mean \pm SD) & $796( \pm 273)$ & $29.47( \pm 25)$ \\
\hline Control (mean \pm SD) & $1877( \pm 325)$ & $69.53( \pm 33)$ \\
\hline bilateral $p$ value & $<0.0001$ & $<0.0001$ \\
\hline
\end{tabular}

*Mann-Whitney for independent samples: considered different when $p \leq 0.05$

**Wilcoxon test: considered different when $p \leq 0.05$

Table 1: Tick counting parameters - Comparison of total detached engorged females at the end of the experiment by Mann-Whitney test and biweekly recovery rate of detached engorged females per animal by Wilcoxon test.

\begin{tabular}{|c|c|c|c|c|c|}
\hline \multirow{2}{*}{ Group } & \multicolumn{3}{|c|}{ Average cattle weight before and after the trial period $(\mathrm{kg})$} & \multicolumn{2}{|c|}{$\begin{array}{l}\text { Average biweekly weight variation during the } \\
\text { trial period }(\mathrm{kg})\end{array}$} \\
\hline & Before & After & bilateral $p$ value & & bilateral $p$ value \\
\hline $\begin{array}{l}\text { Diflubenzuron (mean } \\
\quad \pm \text { SD) }\end{array}$ & $299( \pm 39)$ & $372( \pm 49)$ & $0.0007^{*}$ & $4.8( \pm$ _4.4) & \\
\hline Control (mean \pm SD) & $295( \pm 51)$ & $283( \pm 51)$ & $0.17^{\star *}$ & $-0.4( \pm 1.4)$ & $<0.0001^{*}$ \\
\hline
\end{tabular}

*Wilcoxon (signed-rank test): considered different when $p<0.05$

${ }^{* *}$ Paired sample t-Test: considered different when $\mathrm{p} \leq 0.05$

Table 2: Cattle parameters - Comparison of average cattle weight of each group before and after the experiment (treated group by Wilcoxon test and control group by paired sample $t$-test) and the biweekly weight variation during the trial period by Wilcoxon test

*Wilcoxon (signed-rank test): considered different when $p \leq 0.05$

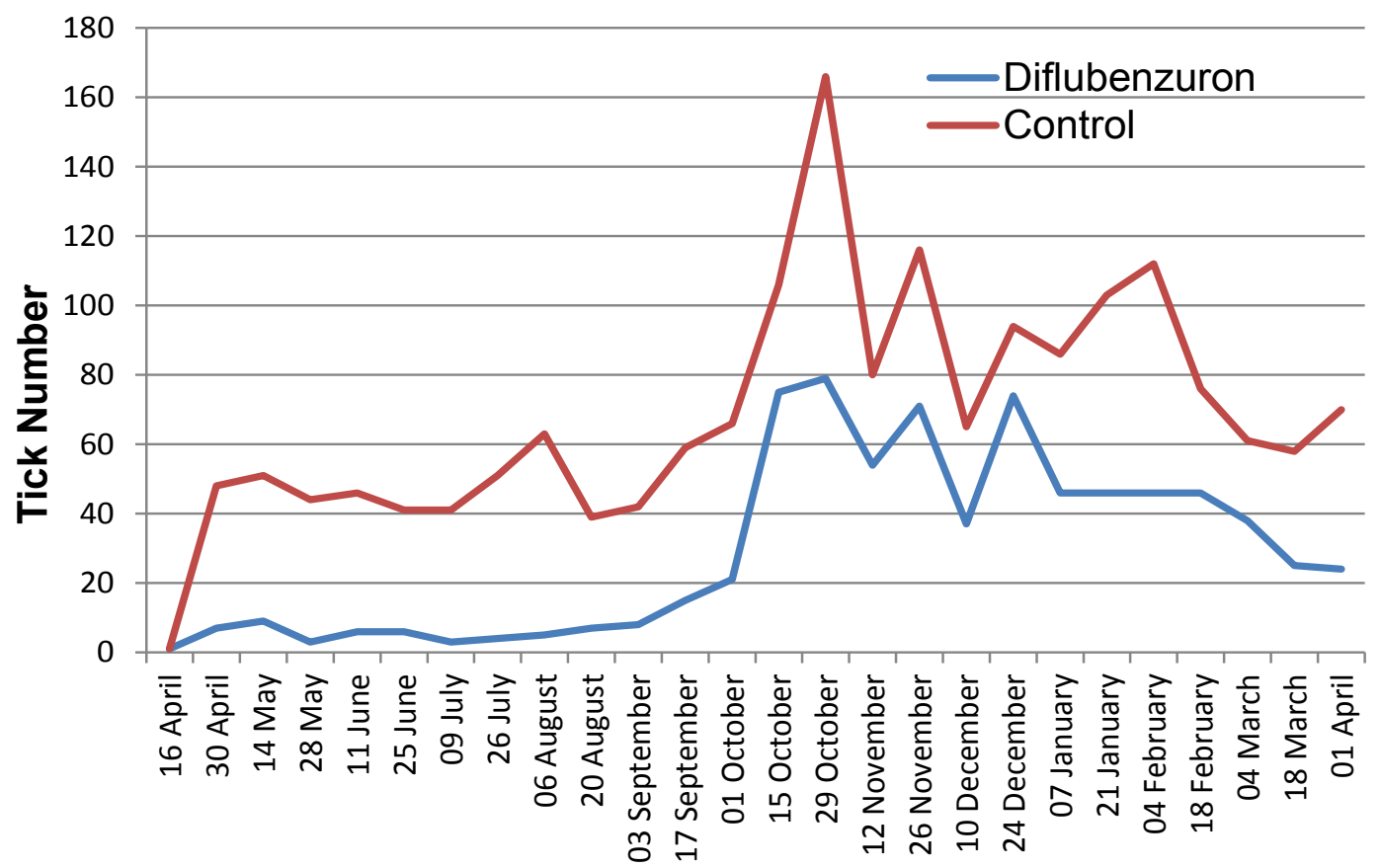

Figure1: Profile of count ticks average variation in a one year period in the groups treated with $3 \%$ diflubenzuron and control. Each group was the result of observations in fifteen animals. 
Citation: Andreotti R, Garcia MV, Matias J, Barros JC, Magalhaes GM, et al. (2015) Diflubenzuron Effectiveness in Cattle Tick (Rhipicephalus Boophilus microplus) Control in Field Conditions. Pharm Anal Acta 6: 373. doi:10.4172/21532435.1000373

Page 4 of 7

fifteen days of treatment were noted increased amount of cell death (Figure 2F) even without the presence of erythrocytes. Is important to note that the histopathology samples came from larvae and nymphs, so it was not possible to assess the ovaries, which is one of the targets of the drug.

The diflubenzuron is a growth regulator, interfering with the chitin deposition and consequently inhibiting cuticle formation, making the most difficult and mitigating the development of larvae and nymphs [16].

The biological information's showed that the individuals from the treated group that are able to survive had a normal development when compared to the control group. We can assume that when there is development the histological observations is not enough to cause damage in the tick.

The field infestation demonstrated that the engorged female ticks from bovines from both groups weighted from 197 to $298 \mathrm{mg}$ when sampled, which is their normal weight, without differences between the groups. Female engorged ticks were incubated for oviposition and larvae viability to be evaluated, and there was no difference between the groups.
The results showed that, in the field infestation test, which lasted one year, the group treated with Diflubenzuron 3\% had the efficacy of $57.6 \%$ considering the efficacy calculation by Cunha et al. [17]. Furthermore, we reported that the reduction occurred significantly during the whole year, since the animals started to absorb the molecule.

The Diflubenzuron functions for all the different insect's larvae phases [14]. Costa [22] observed that the Diflubenzuron in low concentration reduced the dried weight of the Culex pipiens larvae in $27 \%$, what was attributed to the chitin formation inhibition induced by the insecticide. The difference to this study is that here the tick larvae that developed were viable when adults, including their reproductive capacity.

The results found by Silva and Mendes [12] showed that Diflubenzuron was able to inhibit $100 \%$ emergence of the Haematobia irritans adult flies. This means that this product acts on other bovine parasites with different intensity.

Bovine live weight comparison: Regarding bovine weight comparison, both groups had similar average weight $(299 \mathrm{~kg}$ for the group treated with diflubenzuron $3 \%$ and $295 \mathrm{~kg}$ for the control group

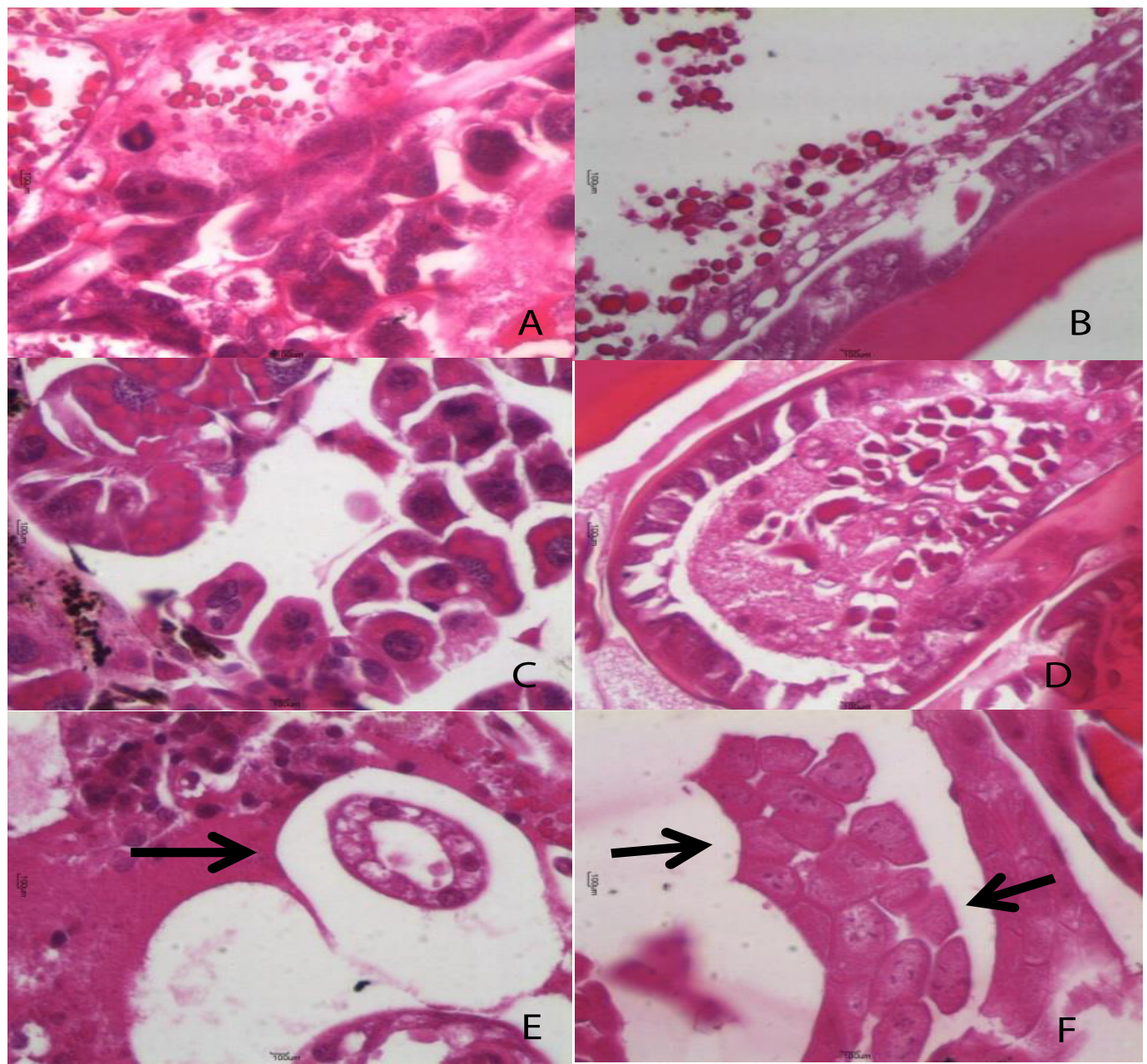

Figure 2: Histology. Photomicrograph of histopathology. HE. Obj 40x. (A) and (B) are controls ticks, (C) tick control at 15 days, (D) tick five days of treatment, (E) tick ten days of treatment, noted karyolysis and vacuolated cytoplasm (arrowhead), (F) tick fifteen days of treatment. Observed increased amount of cell death (arrows). 
in the beginning) (Figure 3). During the experiment period (one year), the treated group with diflubenzuron $3 \%$ gained, on average, $73 \mathrm{~kg}$, while the control group, on average, lost $12 \mathrm{~kg}$ and these variations were considered different at $5 \%$ significance.

A higher weight gain suggests better animal welfare, which means that the animals are potentially better in their reproductive capacity, milk production capacity and better protected for diseases, considering the status of their immune system when using diflubenzuron $3 \%$ in this conditions.

Sutherst et al. [23], in studies on the effects of cattle tick infestation on live weight gain, introduced the concept of the damage coefficient, and showed that there was a linear relationship between the number of ticks engorging and bovine weight loss.

The tick average for the group using diflubenzuron $3 \%$ of 53 individuals associated with the control using acaricides in the animals with more than 100 ticks can improve the live weight development for the host. On the other hand we can assume that the tick average of 125 in the control group is related with live weight loss during a one year of experiment even if it is done treatment with acaricides in animals with more than 100 ticks.

Jonsson et al. [24] estimated that engorging female tick was responsible for the loss of $1.0 \mathrm{~g}$ of body weight and Horn [25] observed that low parasite burden apparently do not produce significant effects that support the results of this work. Reduced live weight gain in tickinfested cattle has been attributed to a specific effect of ticks, which causes appetite loss on bovines as well $[26,24]$.

On the other hand functional immunity reduces production in resistant cows when tick challenge occurs [23]. Immunosuppression by $R$. microplus has been documented by Inokuma et al. [27], who showed that tick infestation reduced the percentage of $\mathrm{T}$ lymphocytes in circulation and also reduced the antibody response. And, tick saliva suppressed the bovine peripheral blood lymphocytes' response in heavily infested cattle.

Number of engorging ticks, nutrition conditions, seasonal variations, breed and their relation with cattle live weight is considered variable and depends on the interaction in the production system, considering the susceptibility of cattle to the effects of a given number of ticks.

Considering weight gain and beef cattle management, in addition, moving the animals to the corral disrupts their activity making them lose up every time they are moved. Therefore, this type of management would affect them even more, making the use of salt an option to mitigate these harms.

Considering that tick control by pulverization was done to intervene and avoid further damage to the animals, it was necessary to do it 22 times in the treated group with diflubenzuron 3\%, while in the control group the pulverization control was done 76 times, in the period of one year. The $57.6 \%$ of tick reduction would be even higher if the intervention was not made to control the situation, what would probably reflect on the animals' weight and health.

The use of acaricides when associated to diflubenzuron 3\% the results showed that there is $71 \%$ of reduction in the use of acaricides leading a protecting more the environment, the risk for animal health and the workers in the farm.
Diflubenzuron has usually been orally administered to cows and, pesticide residues determination included the compound extraction with ethyl acetate, fat removal with hexane, and chromatography analysis by HPLC with UV detection $(254 \mathrm{~nm})$. Diflubenzuron was not detected in milk $(<0.01 \mathrm{mg} / \mathrm{kg})$ indicating that the use of this compound, in adequate doses for achieving a proper insecticide effect, may result in milk considered safe regarding to the presence of diflubenzuron residues [28].

Economic evaluation: This study compares a group treated with Diflubenzuron $3 \%$ and a control group where both have received complementary tick control treatment when the number of ticks reached 100 per animal, which is when assume that the animals have a health risk and start causing economic losses in the supply chain.

In the experiment conditions, the cost per animal treated in the period with Diflubenzuron 3\% was of US\$22.96, while in the control group the cost was of US\$1.82 per animal, which represents $7.9 \%$ of the treated animals cost.

Considering milk production estimation, the damage to milk production caused by cattle ticks was recently evaluated by Rodrigues and Leite [29], whom estimated that ticks were responsible for a $90.24 \mathrm{~L}$ reduction in milk production per cow per lactation in Brazil. Considering the results for Brazil, we can estimate that for a group of 15 cows, in the period of one year, the loss would amount to USD\$ 595.58. Would be a benefit when the treatment is used and in Brazilian conditions the strategic treatment is around 5 aspersions of acaricides with 21 days of interval in the final of dry period that cost would be around US\$ 1.82 per animal.

Similar data was found by Jonsson et al. [24] who estimated total loss in milk production for each cow over the experimental period was 92.5. Tick infestation can lead not only to diminished lactation, but also to the death of hosts.

\section{Conclusion}

Based on tick biology and histology we can affirm in this experiment that the Diflubenzuron 3\% did not affect the development of ticks that survived the parasitic phase. The effect is in the tick larvae only and the efficacy is about $54.6 \%$ of protection using Diflubenzuron $3 \%$ in the salt.

It is possible to conclude that the Diflubenzuron $3 \%$, added to mineralized salt in the indicated dosages, has reduction of average of ticks in at least $58 \%$ with a good efficiency in bovine tick control and should be associated with other acaricide treatment, leading to a higher efficiency in tick control.

The use of acaricides when associated to diflubenzuron 3\% reduce in $71 \%$ the use these acaricides leading a protecting more the environment, the risk for animal health and the workers in the farm.

The cost of acaricide in aspersion represent when compared with diflubenzuron $3 \%$ only $7.9 \%$. The use of diflubenzuron $3 \%$ associated with chemical control is an effective proposal to cattle tick control with low contamination that should be thought by the production chain their cost/benefit taking into account the economic and environmental issues also the diflubenzuron act in other ectoparasites of interest in the productive sector.

\section{Acknowledgements}

We would to thank the support of CNPq, CAPES and FUNDECT-MS. 
Citation: Andreotti R, Garcia MV, Matias J, Barros JC, Magalhaes GM, et al. (2015) Diflubenzuron Effectiveness in Cattle Tick (Rhipicephalus Boophilus microplus) Control in Field Conditions. Pharm Anal Acta 6: 373. doi:10.4172/21532435.1000373

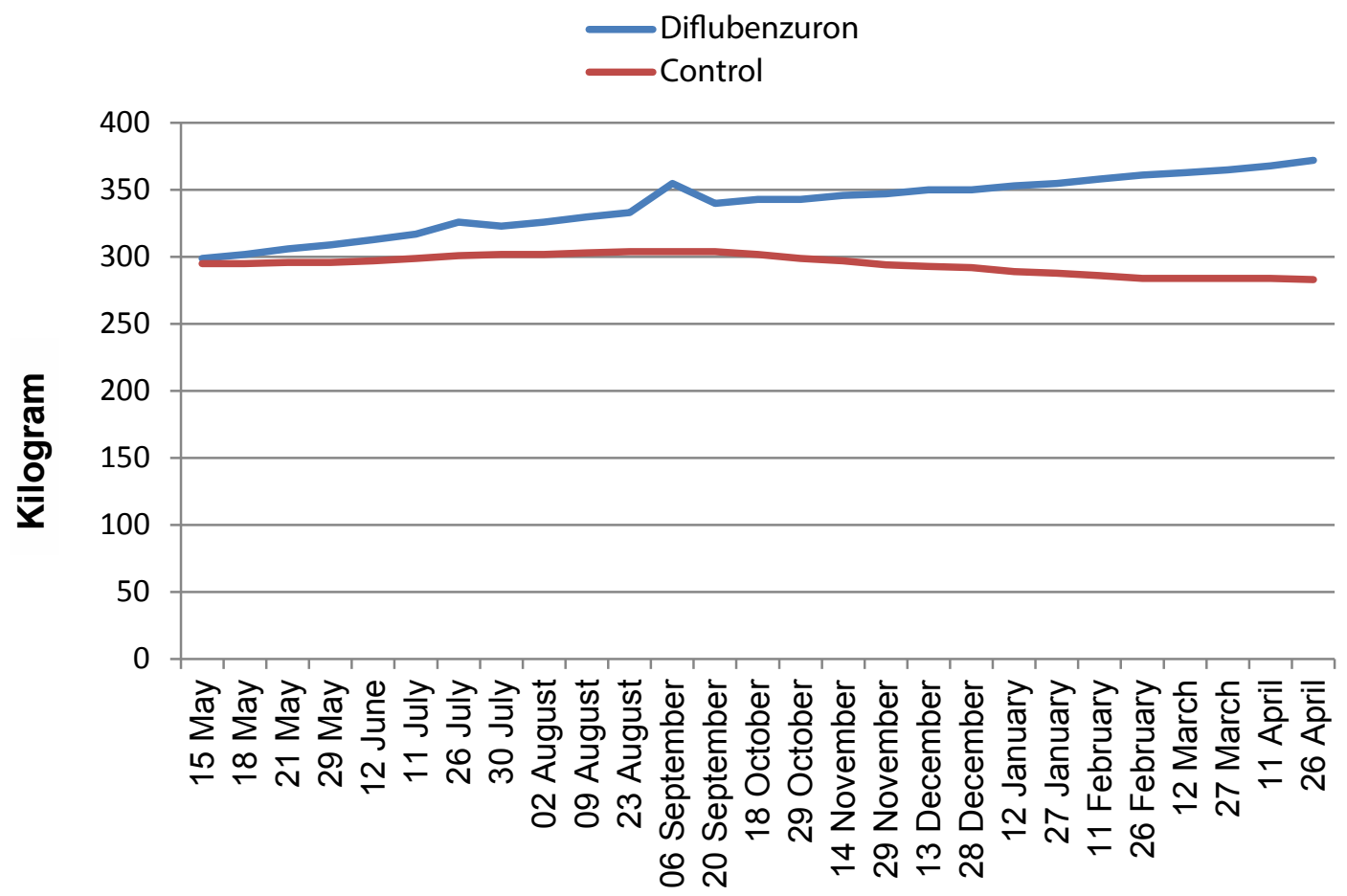

Figure 3: Bovine Live weight average variation during one year of experiment.

\section{References}

1. Willadsen $P$, Jongejan $F(1999)$ Immunology of the tick-host interaction and the control of ticks and tick-borne diseases. Parasitol Today 15: 258-262.

2. Grisi L, Leite RC, Martins JRS, Barros ATM, Andreotti R, et al. (2014) Reassessment of the potential economic impact of cattle parasites in Brazil. Braz J Vet Parasitol 23: 150-156.

3. Andreotti R, Guerrero FD, Soares MA, Barros JC, Miller RJ, et al. (2011) Acaricide resistance of Rhipicephalus (Boophilus) microplus in the Brazilian state of Mato Grosso do Sul Rev Bras. Parasitol Vet 20: 127-133.

4. Rodriguez-Vivas RI, Rivas AL, Chowell G, Fragoso SH, Rosario CR, et al. (2007) Spatial distribution of acaricide profiles (Boophilus microplus strains susceptible or resistant to acaricides) in southeastern Mexico. Vet Parasitol 146: 158-169.

5. Guerrero FD, Andreotti R, Bendele KG, Cunha RC, Miller RJ, et al. (2014) Rhipicephalus microplus aquaporin as an effective vaccine antigen to protect against cattle tick infestations. Parasites \& Vectors 7: 475.

6. Furlong J, Martins JR, Prata MCA (2007) O carrapato dos bovinos e a resistência: temos o que comemorar?. A hora veterinária 27: 26-32.

7. Furlong, J (2004) Controle estratégico do carrapato dos bovinos. A Hora Veterinária 23: 53-56.

8. Guglielmone AA, Kunz SE, Volpogni MM, Anziani OS, Flores SG (1998) Diagnóstico de poblaciones de La Haematobia irritans (Díptera: Muscidae) resistentes a La cipermetrina em Santa Fé. Argentina. Rev de Med Vet 79: 353-356.

9. Barros ATM (2002) Desenvolvimento de Haematobia irritans em massas fecais de bovinos mantidas em laboratório. Pesq Agropec Bras 37: 217-221.

10. Oliveira AAA, Azevedo HC, Melo CB, Barros ATM (2006) Suscetibilidade da mosca-dos-chifres (Haematobia irritans) a inseticidas nos tabuleiros costeiros de Alagoas. Bahia e Sergipe Rev Bras Parasitol Vet 15: 65-70.

11. Lyra JRM, Ferraz JMG, Silva APP (1998) Acción de inibidores de la sintesis de La quitina em La reproducción de Spodoptera littoralis (Boisd.) (Lepdoptera: Noctuidae). Soc Entomol Brasil 27: 569-576.
12. Silva JJ, Mendes J (2002) Effects of Diflubenzuron on immature stages of Haematobia irritans (L.) (Diptera: Muscidae) in Uberlandia. State of Minas Gerais, Brazil. Mem Inst Oswaldo Cruz 97: 679-682.

13. Braga IA, Valle D (2007) Aedes aegypti: inseticidas, mecanismos de ação e resistência. Epidemiol Serv Saúde 16: 179-293.

14. Grosscurt AC (1978) Diflubenzuron: some aspects of its ovicidal and larvicidal mode of action and na evaluation of its pratical possibilities. Pesticide Science 9: 373-386.

15. Graf JF (1993) The role of insect growth regulators in arthropod control. Parasitology Today 9: 471-474.

16. Hopkins DE, Chamberlain WF (1976) Diflubenzuron relationship between age of exposure immature horn flies and inhibition of maturation. Southwestern Entomologist 1: 114-117.

17. Cunha RC, Andreotti R, Garcia MV, Aguirre AAR, Leitão (2013) Calculation of the efficacy of vaccines against tick infestations on cattle. Rev Bras Parasito Vet 22: 1-8.

18. Villares JB. Climatologia Zootécnica. III (1941) Contribuição ao estudo da resistência e susceptibilidade genética dos bovinos ao Boophilus microplus. Bol. Indústria Anim 4: 60-86.

19. Davey RB, Osburn RL, Miller JA (1984) Ovopositional and morphological comparisons of Boophilus microplus (Acari: Ixodidae) collected from differents geografical areas. Ann Entomol Soc Am 77: 1-5.

20. Bechara GH, Heller-Haupt A, Varma MGR. Langi AO, Trinder PKE (1989) Development of immunity to Rhipicephalus appendiculatus in hamsters (Mesocricetus auratus). Imunobiology 4: 176.

21. Oliveira BR, Gomes, AG, Santos, RS (2009) Controle do Carrapato Boophilus microplus com Diflubenzuron $3 \%$, em fazenda de gado de corte no município de Pirenópolis Goiás. A Hora Veterinária 168: 46-47.

22. Costa, F.M (2007) Avaliação da atividade inseticida do regulador de crescimento de insetos Diflubenzuron contra Anopheles darling Root, 1926 (Dipetra, Culididae). em condições de laboratório. 2007. 61 f. Dissertação (Mestrado em Ciências Biológicas) - Universidade Federal do Amazonas UFAM, Manaus. 
Citation: Andreotti R, Garcia MV, Matias J, Barros JC, Magalhaes GM, et al. (2015) Diflubenzuron Effectiveness in Cattle Tick (Rhipicephalus Boophilus microplus) Control in Field Conditions. Pharm Anal Acta 6: 373. doi:10.4172/21532435.1000373

23. Sutherst RW, Maywald GF, Kerr JD, Stegeman DA (1983) The effect of cattle tick (Boophilus microplus) on the growth of Bos indicus $\times$ B. taurus steers. Aust J Agri Res 34: 317-327.

24. Jonsson NN, Mayer DG, Matschoss AL, Green PE, Ansell J (1998) Production effects of cattle tick (Boophilus microplus) infestation of high yielding dairy cows. Vet Parasitol 78: 65- 77.

25. Horn SC (1983) Prováveis prejuízos causados pelos carrapatos no Brasil. (2 edition) Brasília.

26. Seebeck RM, Springell PH, O'Kelly JC (1971) Alterations in the host metabolism by the specific and anorectic effects of the cattle tick (Boophilus microplus) I. Food intake and body weight growth Aust J biol Sci 24: 373-380.
27. Inokuma H, Kellin RL, Kemp DH, Willadsen P (1993) Effects of cattle tick (B. microplus) infestation on the bovine immune system. Vet Parasitol, Amsterdam 47: 107-118.

28. Tfouni SAV, Furlani RPZ, Araújo JD, Souza RM (2007) Determination of pesticide residues presence in milk from cows treated with diflubenzuron. Rev Inst Adolfo Lutz, São Paulo 66: 230-233.

29. Rodrigues DS, Leite RC (2013) Economic impact of Rhipicephalus (Boophilus) microplus: estimate of decreased milk production on a dairy farm. Arq Bras Med Vet Zootec 65: 1570-1572. 